\title{
An Investigation into the Body Mass Index Levels of Female University Students and Women from Different Ages
}

\author{
İskender Güler (Corresponding author) \\ Department of Physical Education and Sports, Faculty of Education \\ Amasya University, Amasya, Turkey \\ E-mail: iskender.guler@amasya.edu.tr
}

Received: September 18, 2021

Accepted: October 16, 2021

Published: November 11, 2021

doi:10.5296/jei.v7i2.19021

URL: https://doi.org/10.5296/jei.v7i2.19021

\begin{abstract}
The purpose of this study was to determine and to evaluate the Body Mass Index (BMI) levels of female students between the ages of 20 and 30 who study at Amasya University and women between the ages of 40 and 60 who live in Amasya since BMI levels are of great importance to determine the body fat levels for a healthy body. We recruited 910 female students and 688 women. All participants had no health problems. The formula we used for BMI levels of the participants was BMI $=\mathrm{kg} / \mathrm{m}^{2}$. We relied on such parameters as mean, standart deviation, minimum and maximum values for statistical analyses of the data. We conducted the independent samples $t$ test to see if there was any statistically significant differences between groups. The findings showed that female university students' body mass index levels were $21.84 \mathrm{~kg} / \mathrm{m}^{2}$, while women living in Amasya had $27.68 \mathrm{~kg} / \mathrm{m}^{2}$ body mass index levels. We found a statistically significant difference in the body mass index levels between the groups in favor of the female university students. We conclude that female university students between the ages of 20 and 30 who study at Amasya University had normal levels of BMI when compared with women between the ages of 40 and 60 who live in Amasya.
\end{abstract}

Keywords: University students, Women, Body mass index, Body fat level

\section{Introduction}

People with a sedentary lifestyle mostly suffer from problems in some organ functions without any pathological condition and therefore their health problems increase. In order to prevent or delay such problems, which increase with age, for a healthy, productive and fit life, a balanced diet and physical activity in a regular lifestyle are of great importance. However, 
today's technological developments and prosperity lead people to have a sedentary lifestyle from childhood and cause a decrease in physical activity levels (Şanlı \& Atalay Güzel, 2009).

Body Mass Index (BMI) is an easy and practical measurement technique in the field, calculated with the content of height and weight in determining obesity and its level. It is related to the amount of total body fat. According to the BMI data of the World Health Organization (WHO), the fat ratios of those living in developing countries are classifiedas follows: If the BMI is below $18.5 \mathrm{~kg} / \mathrm{m}^{2}$, it is considered as underweight, $18.5-24.9 \mathrm{~kg} / \mathrm{m}^{2}$ is normal weight, $25-29.9 \mathrm{~kg} / \mathrm{m}^{2}$ is overweight, $30 \mathrm{~kg} / \mathrm{m}^{2}$ and over is obese, and over $40 \mathrm{~kg} / \mathrm{m}^{2}$ is morbidly obese (Kaya \& Özçelik, 2008; World Health Organization, 1995).

A BMI between $20-25 \mathrm{~kg} / \mathrm{m}^{2}$ means that there is not much visceral adipose tissue and that it is balanced, and there is no increase in cardiovascular risk if more than $10 \mathrm{~kg}$ is not gained after 18 years of age. A BMI between $25-29.9 \mathrm{~kg} / \mathrm{m}^{2}$ is defined as obesity, while if this value is $30 \mathrm{~kg} / \mathrm{m}^{2}$ and above, it is regarded obesity. A BMI between $26-30 \mathrm{~kg} / \mathrm{m}^{2}$ is associated with a low risk of cardiovascular diseases, and a BMI between $31-35 \mathrm{~kg} / \mathrm{m}^{2}$ is linked to a moderate increase in risk. A BMI of more than $35 \mathrm{~kg} / \mathrm{m}^{2}$ means that there is a high or very high risk of cardiovascular disease (Solmaz \& Akbulut, 2018). According to the data of WHO in 2014, the number of overweight people over the age of 18 is 1.9 billion, and 600 million of them are obese. According to WHO's post-2009 data on Turkey, it has been reported that $3.5 \%$ of adults in our country are extremely thin, $40.1 \%$ are normal, $40.3 \%$ are overweight, and $16.1 \%$ are obese. Based on the ratio of the population, whose body mass index is above 25 according to $\mathrm{WHO}$, to the total population in 2005-2014, the BMI values of individuals in Turkey have increased from $63.5 \%$ to $68.4 \%$ in women with a regular increase every year in this ten-year period; in males, it has been found to increase from $56.8 \%$ to $63.0 \%$ (Şiriny1ld1z et al., 2017).

Sedentary life significantly affects women's health and also leads to many health problems. Despite the traditional view that coronary artery disease mostly affects men, studies have shown that this disease affects women to the same extent. There are many studies showing the relationship between the frequency and course of coronary heart disease and the level of physical activity (Glassberg \& Balady, 1999). There is also limited evidence on the prevalence of obesity and thinness. However, it is important financially and physically to determine being overweight or obesity at an early age and take precautions. BMI, which is obtained by dividing the square of the height in meters by the body weight in kilograms $\left(\mathrm{kg} / \mathrm{m}^{2}\right)$, is a frequently used method for the diagnosis of being overweight or obesity, or for identifying healthy individuals and classifying them according to their body structures (Kaya \& Özçelik, 2009). BMI is an objective criterion used in the evaluation of nutritional status and obesity in both children and adults and therefore it is recommended (Sarria et al., 2001; Sivasli et al., 2006). In Turkish society, people, particularly women, have sedentary lifestyles.

Based on these statistics and scientific information, this present study was intended to determine and to evaluate the Body Mass Index (BMI) levels of female students between the ages of 20 and 30 who study at Amasya University and women between the ages of 40 and 60 who live in Amasya since BMI levels are of great importance to determine the body fat levels for a healthy body. 


\section{MIN Macrothink}

\section{Method}

\subsection{Participants}

We recruited 910 healthy female students between the ages of 20 and 30 and studying at different departments of Amasya University and 688 healthy women between the ages of 40 and 60 and living in Amasya. Some of the women participants regularly work in a profession, whereas some don't.

\subsection{Data Collection}

In the research, a tape measure was used to measure the height and a $0.5 \mathrm{~kg}$ precision scale was employed to measure the body weight to collect the data. In taking the measurements, healthy and volunteer students by visiting the departments of some faculties and colleges in Amasya University for female students between the ages of 20 and 30 studying at Amasya University; For women between the ages of 40 and 60 living in Amasya, some neighborhoods and districts in Amasya Center were visited, taking into account the socioeconomic level, and measurements were taken from healthy volunteer female participants. Length with socks without shoes; body weight measurements were taken with loose dresses. However, in the evaluation of body weight results, an average garment was determined and deducted from the measurement result. The formula " $\mathrm{BMI}=\mathrm{kg} / \mathrm{m}^{2}$ " was used to determine the BMI levels of all participants.

\subsection{Data Analysis}

We relied on such parameters as mean, standart deviation, minimum and maximum values for statistical analysis of the data. We conducted the independent samples $t$ test to see if there was any statistically significant differences between groups.

\section{Findings}

The findings and their evaluations are presented in tables below.

Table 1. Demographic information

\begin{tabular}{|l|l|l|l|l|l|l|}
\hline \multirow{2}{*}{ Variables } & \multicolumn{2}{|c|}{ X \pm Sd } & \multicolumn{2}{c|}{ Minimum } & \multicolumn{2}{c|}{ Maximum } \\
\cline { 2 - 7 } & $\begin{array}{l}\text { 20-30 years } \\
\text { (n: } 910)\end{array}$ & $\begin{array}{l}\text { 40-60 years } \\
\text { (n: } 688)\end{array}$ & $\mathbf{2 0 - 3 0 ~ y e a r s ~}$ & 40-60 years & 20-30 years & 40-60 years \\
\hline Age (years) & $22.60 \pm 1.89$ & $47.55 \pm 6.17$ & 20 & 40 & 30 & 60 \\
\hline Height $(\mathrm{m})$ & $1.63 \pm 0.05$ & $1.62 \pm 0.05$ & 1.50 & 1.50 & 1.84 & 1.83 \\
\hline Weight $(\mathrm{kg})$ & $58.14 \pm 6.52$ & $72.64 \pm 10.11$ & 43 & 43 & 84 & 100 \\
\hline BMI $\left(\mathrm{kg} / \mathrm{m}^{2}\right)$ & $21.84 \pm 2.22$ & $27.68 \pm 4.10$ & 16.38 & 16.80 & 30.22 & 40.27 \\
\hline
\end{tabular}


When Table 1 is examined, the mean age, height, weight and BMI of the research group were 22.60 years, $1.63 \mathrm{~m}, 58.14 \mathrm{~kg}$ and $21.84 \mathrm{~kg} / \mathrm{m}^{2}$ for those aged $20-30$, while those aged $40-60$ years were 47.55 years, $1.62 \mathrm{~m}, 72.64 \mathrm{~kg}$ and $27.68 \mathrm{~kg} / \mathrm{m}^{2}$.

Table 2. The statistical differences among women based on their ages and demographic variables

\begin{tabular}{|l|l|l|l|}
\hline \multirow{2}{*}{ Variables } & \multicolumn{2}{|c|}{ X \pm Sd } & \multirow{2}{*}{$\mathbf{p}$} \\
\cline { 2 - 4 } & $\mathbf{2 0 - 3 0}$ years $(\mathrm{n}=910)$ & $\mathbf{4 0 - 6 0}$ years $(\mathrm{n}=688)$ & \\
\hline Height $(\mathrm{m})$ & $1.63 \pm 0.05^{* *}$ & $1.62 \pm 0.05$ & 0.00 \\
\hline Weight $(\mathrm{kg})$ & $58.14 \pm 6.52$ & $72.64 \pm 10.11^{* *}$ & 0.00 \\
\hline BMI $\left(\mathrm{kg} / \mathrm{m}^{2}\right)$ & $21.84 \pm 2.22$ & $27.68 \pm 4.10^{* *}$ & 0.00 \\
\hline
\end{tabular}

Note. $*: \mathrm{p}<0.05 ; * *: \mathrm{p}<0.01$

The mean height, weight and BMI of the research group were $1.63 \mathrm{~m}, 58.14 \mathrm{~kg}$ and 21.84 $\mathrm{kg} / \mathrm{m}^{2}$ in the 20-30 age group, respectively, while those aged 40-60 years were $1.62 \mathrm{~m}, 72.64$ $\mathrm{kg}$ and $27.68 \mathrm{~kg} / \mathrm{m}^{2}$. Based on these, there were statistically significant differences $(\mathrm{p}<.01)$ between the mean height, weight and BMI of women at different ages (Table 2).

Table 3. BMI distributions of women

\begin{tabular}{|c|c|c|c|c|c|c|}
\hline \multirow{3}{*}{ Groups } & \multirow{3}{*}{$\mathbf{n}$} & \multicolumn{4}{|c|}{ BMI $\left(\mathrm{kg} / \mathrm{m}^{2}\right)$ levels } & \multirow{3}{*}{ Total } \\
\hline & & Less than 18.5 & Between 18.5-24.9 & Between 25-29.9 & 30 and above & \\
\hline & & $\mathbf{f} / \%$ & $\mathbf{f} / \%$ & $\mathbf{f} / \%$ & $\mathbf{f} / \%$ & \\
\hline \multirow{2}{*}{$20-30$ years } & 910 & $31 / 3.41$ & $781 / 85.82$ & $97 / 10.66$ & $1 / 0.11$ & 100 \\
\hline & 1598 & $31 / 1.94$ & $781 / 48.87$ & $97 / 6.10$ & $1 / 0.06$ & 100 \\
\hline \multirow{2}{*}{$40-60$ years } & 688 & $6 / 0.87$ & $191 / 27.76$ & $292 / 42.44$ & $199 / 28.92$ & 100 \\
\hline & 1598 & $6 / 0.38$ & $191 / 11.95$ & $292 / 18.27$ & $199 / 12.45$ & 100 \\
\hline Total & 1598 & $37 / 2.32$ & $972 / 60.83$ & $389 / 24.34$ & $200 / 12.52$ & 100 \\
\hline
\end{tabular}

In the study group, those whose BMI percentages were below $18.5 \mathrm{~kg} / \mathrm{m}^{2}$, between $18.5-24.9$ $\mathrm{kg} / \mathrm{m}^{2}$, between $25-29.9 \mathrm{~kg} / \mathrm{m}^{2}$ and $30 \mathrm{~kg} / \mathrm{m}^{2}$ and above in-group/general group were measured. Those $20-30$ years old were measured as $3.41 / 1.94 ; 85.82 / 48.87 ; 10.66 / 6.10$ and $0.11 / 0.0$, respectively. On the other hand, for those aged $40-60$, they were calculated as 
$0.87 / 0.38 ; 27.76 / 11.95 ; 42.44 / 18.27$ and $28.92 / 12.45$ respectively. The percentages of BMI below $18.5 \mathrm{~kg} / \mathrm{m}^{2}$, between $18.5-24.9 \mathrm{~kg} / \mathrm{m}^{2}$, between $25-29.9 \mathrm{~kg} / \mathrm{m}^{2}$, and $30 \mathrm{~kg} / \mathrm{m}^{2}$ and above of the whole research group were $2.32 ; 60.83 ; 24.34$ and 12.52 respectively(Table 3 ).

\section{Discussion and Result}

In the literature, BMI practically is one of the indicators of nutritional status and total body fat amount in humans (Sarria et al., 2001; Sivaslı et al., 2006; Solmaz and Akbulut, 2018). In this sense, a BMI between $20-25 \mathrm{~kg} / \mathrm{m}^{2}$ means that the visceral adipose tissue is balanced, and if more than $10 \mathrm{~kg}$ is not gained after the age of 18-20, there is no increase in cardiovascular risk (Solmaz \& Akbulut, 2018). On the other hand, in this present study, we found that the average body weight of university students aged 20-30 and women aged 40-60 in Amasya is approximately $14 \mathrm{~kg}$ (Table 1). Similarly, Onat et al. (2020) evaluated the indicators of obesity in the 10-year follow-up of adults and found that obesity has become widespread in adults over the last 10 years, and the average BMI has increased by $1.29 \mathrm{~kg} / \mathrm{m}^{2}$ in men and $1.26 \mathrm{~kg} / \mathrm{m}^{2}$ in women (corresponding to an average of 3 and $4 \mathrm{~kg}$ obesity) in 10 years. This finding reflects obesity, with an increase in mean BMI of 1.3 units, indicating that adult weight gain is above normal with age. In the same study, it is highlighted that the prevalence of obesity in the population over the age of thirty, excluding population growth, increased by $47 \%$ compared to 10 years ago to 8.1 million in 2000 . In this case, it is not surprising that there was a significant $(\mathrm{p}<0.01)$ difference between the mean BMI of university students aged 20-30 and women aged 40-60 in Amasya and our findings corroborates with those by Onat et al. (2020).

It should also be kept in mind that as age progresses, the balance between BMI and BFP (body fat percentage) decreases, especially in women, the highest level of balance in women is in the 20-29 age group, and the balance between BMI and BYY decreases along with age. It is also stated that this may be due to the lower amount of fat in women aged 20-29 (Büyükakın, 2017; Doğan \& Öner, 2015). In a study conducted on university students, it is stated that the overweight and obesity values determined by BMI values are below the values seen in the advanced age groups in our country's national studies, indicating an increase in the prevalence of obesity due to advancing age (Bektaş et al., 2014). It should also be taken into account that the biological composition of women (such as the hormone estrogen) increases fat storage (Bektaş et al., 2014; Moran et al., 1996). Although this information shows that the result of this study can be considered normal, it rather supports Solmaz and Akbulut (2018) that not gaining more than $10 \mathrm{~kg}$ after 18-20 years of age will not create any increase in cardiovascular health risk. Therefore, the course of this study is that women aged 40-60 years in Amasya are overweight.

In several studies in which obesity was evaluated by BMI and other methods (e.g., Bektaş et al., 2014; Büyükakın, 2017; Chukwunonso \& Ijeh, 2012; Romero-Corral et al., 2008; Wang et al., 2010; WHO, 2004), the frequency of overweight and obese people was determined as both high and low. Büyükakın (2017) concluded that in the study on the evaluation of the compatibility of two different methods used in the diagnosis and monitoring of obesity in adults, the frequency of overweight and obese according to BMI measurements was $59.0 \%$; 
According to BFP measurements, the frequency of those with high fat percentage was determined as $36.0 \%$. Büyükakın (2017) stated that this finding is in contrast to the findings of some studies in the literature. In a study conducted in the United States (USA) related to obesity, it was reported that more than half of obese individuals were determined as normal or overweight by BMI according to BFP, which showed an unacceptably low sensitivity and obesity was higher than the level determined by BMI (Romero-Corral et al., 2008). Chukwunonso and Ljeh (2012) found the frequency of overweight and obese people according to BMI measurements to be lower than BFP in their study conducted in Nigeria between 18-29 years old women and men. In another study on the comparison of the effectiveness of BMI and BIA (Bioelectrical Impedance Analysis) methods in the evaluation of obesity in individuals aged 20-30 years, significant correlations were found between BMI and BYY, and it was stated that BMI predicted obesity frequency lower in both genders (Bektaş et al., 2014). In a study conducted in China in which BMI and BMI were compared in the evaluation of obesity, the frequency of obese patients was found to be lower in BMI measurements than in BMI measurements (Wang et al., 2010). However, the available data do not show that there is a clear BMI cut-off point for all Asians associated with overweight or obesity. The cut-off point of the observed risk ranges from $22-25 \mathrm{~kg} / \mathrm{m}^{2}$ for different Asian populations and between $26-31 \mathrm{~kg} / \mathrm{m}^{2}$ for high risk. As a matter of fact, the World Health Organization (WHO) recommends different BMI cut-off points for Asian populations (WHO, 2004). This situation brings to mind that we may need to use BMI cut-off points specific to our society for our country, but in some studies in which obesity was evaluated by BMI and other methods (Bektaş et al., 2014; Büyükakın, 2017; Chukwunonso \& Ijeh, 2012; Romero-Corral et al., 2008; Wang et al., 2010; WHO, 2004) show that BMI results can be practically reliable in determining nutritional status and total body fat amount.

We conclude that the BMI percentages of overweight and obese women in-group/general group were 10.77/6.16 in women aged 20-30, respectively; It was determined as 71.36/30.72 in women aged 40-60 (Table 3). Therefore, while the BMI percentages of overweight and obese women aged 20-30 are low, it is seen higher in women aged 40-60. This finding has been determined by the studies of Büyükakın (2017), and Doğan and Öner (2015) that the amount of fat is lower in women aged 20-29; Bektas et al. (2014), Büyükakın (2017), Chukwunonso and Ijeh (2012), Romero-Corral et al. (2008), Wang et al. (2010), and WHO (2004) studies are in parallel in terms of determining the frequency of overweight and obese individuals as both high and low in BMI measurements.

As a result, in terms of health, it can be said that female students between the ages of 20-30 studying at Amasya University have a more balanced diet and normal body fat when compared with women between the ages of 40-60 living in Amasya.

\section{References}

Bektaş, Y., Gültekin, T., Akın, G., \& Önal, S. (2014). Obezitenin Değerlendirilmesinde Beden Kitle İndeksi ve Biyoelektrik Empedans Metotlarının Etkinliğinin Karşılaştırılması. Antropoloji, 28, 67-86. https://doi.org/10.1501/antro_0000000303

Büyükakın, B. (2017). Erişkinlerde Obezite Tanı ve İzleminde Kullanılan İki Farklı Yöntemin 
Uyumunun Değerlendirilmesi (Uzmanlık Tezi, Pamukkale Üniversitesi Tıp Fakültesi Halk Sağlı̆̆ Anabilim Dalı).

Chukwunonso, E. E., \& Ljeh, I. I. (2012). Obesity in Young-Adult Nigerians: Variations in Prevalence Determined by Anthropometry and Bioelectrical İmpedance Analysis, and the Development of \% Body Fat Prediction Equations. International Archives of Medicine, 5, 22. https://doi.org/10.1186/1755-7682-5-22

Doğan, B., \& Öner, C. (2015). Obez Bireylerde İki Farklı Yöntemle Hesaplanan Vücut Yă̆ Oranının Antropometrik Değerler ve Lipit Parametreleriyle İlişkisi. FNG \& Bilim Tıp Dergisi, 1(3), 124-128. https://doi.org/10.5606/fng.btd.2015.023

Kaya, H., \& Özçelik, O. (2009). Vücut Bileşimlerinin Değerlendirilmesinde Vücut Kitle İndeksi ve Biyoelektrik İmpedans Analiz Metodlarının Etkinliğinin Yaş ve Cinsiyete Göre Karşılaştırılması. F.Ü. Săg. Bil. Tip. Derg., 23(1), 01-05.

Moran, C., Garcia-Hernandez, E., Cortes, M. A., Calzada, L., Salazar, L., \& Bermudez, J. A. (1996). Estradiol and progesterone endometrial receptors and body fat distribution in obese women. Gynecol Obstet Invest., 42(2), 117-9. https://doi.org/10.1159/000291916

Onat, A., Keleş, İ., Sansoy, V., Ceyhan, K., Uysal, Ö., Çetinkaya, A., ... Başar, Ö. (2020). Yetişkinlerimizin 10-yıllık Takibinde Obezite Göstergeleri Artışta: Beden Kitle Indeksi Erkeklerde Koroner Olayların Bağımsız Ongördürücüsü. Retrieved from https://www.journal agent.com/tkd/pdfs/TKDA_29_7_430_436.pdf

Romero-Corral, A., Somers, V. K., Sierra-Johnson, J., Thomas, R. J., Collazo-Clavell, M. L., Korinek, J., ... Lopez-Jimenez, F. (2008). Accuracy of body mass index in diagnosing obesity in the adult general population. Int J Obes (Lond), 32, 959-966. https://doi.org/10.1038/ ijo.2008.11

Şanlı, E., \& Atalay Güzel, N. (2009). Öğretmenlerde Fiziksel Aktivite Düzeyi-Yaş, Cinsiyet ve Beden Kitle İndeksi İlişkisi. Gazi Beden Eğitimi ve Spor Bilimleri Dergisi, XIV(3), 23-32.

Sarria, A., Moreno, L. A., Garcia-Llop, L. A., Fleta, J., Morellon, M. P., \& Bueno, M. (2001). Body mass ndex, triceps skinfold and waist circumference in screening for adiposity in male children and adolescents. Acta Paediatr, 90, 387-392. https://doi.org/10.1080/0803525017 50126195

Şirinyıldız, F., Cesur, G., Alkan, A., \& Ek, R. O. (2017). Beden Eğitimi ve Spor Yüksekokulu Öğrencilerinin Vücut Kitle İndeksi Farkındalığının Belirlenmesi. Smyrna Tıp Dergisi, 1-6.

Sivaslı, E., Bozkurt, A. İ., Özçırpıcı, B., Şahinöz, S., \& Coşkun, Y. (2006). Gaziantep Yöresinde 7-15 Yaşındaki Çocuklarda Vücut Kitle İndeksi Referans Değerleri. Çocuk Să̆lı̆̆ ve Hastalıkları Dergisi, 49, 30-35.

Solmaz, H., \& Akbulut, M. (2018). Obezite ve Kalp. Firat Med J, 23(Suppl.), 30-34.

Wang, C., Hou, X., Zhang, M., Bao, Y., Zou, Y., Zhong, W., ... Jia, W. (2010). Comparison of Body Mass Index with Body Fat Percentage in the Evaluation of Obesity in Chinese. 


\section{Macrothink}

Biomedical and Environmental Sciences, 23, 173-179. https://doi.org/10.1016/S0895-3988 (10)60049-9

WHO Expert Committee. (1995). Physical Status: The Use and Interpretation of Epidemiology (pp. 46-55). World Health Organization.

WHO Expert Consultation. (2004). Appropriate body-mass index for Asian populations and its implications for policy and intervention strategies. Lancet, 363, 157-63. https://doi.org/ $10.1016 / \mathrm{S} 0140-6736(03) 15268-3$

\section{Copyright Disclaimer}

Copyright for this article is retained by the author(s), with first publication rights granted to the journal.

This is an open-access article distributed under the terms and conditions of the Creative Commons Attribution license (http://creativecommons.org/licenses/by/3.0/). 